\title{
WHAT WE KNOW ABOUT THE ENVIRONMENTAL POLICY: AN INDUCTIVE TYPOLOGY OF THE RESEARCH
}

\section{Elisabeth Albertini}

\begin{abstract}
Environmental performance is a multidimensional concept that is difficult to measure since it concerns either the pollution generated by companies, their energy consumption and their different environmental policies. Academic research has used objective and/or non-objective indicators to measure this performance, dealing with both its managerial and measurement dimensions. This paper provides an inductive typology of the academic work concerning environmental policy through a computerized content analysis of 151 articles from 1992 to 2014 related to the management and measurement of environmental performance. The results highlight four major themes around which the academic research is organized: the relationship between environmental and financial performance, environmental performance under stakeholder engagement and institutional pressures, the strategic management of environmental performance, and increasing awareness of the sustainable development issue. Environmental performance research has evolved from a quantitative towards a more managerial dimension, highlighting the integration of performance within the management of a corporate business strategy.
\end{abstract}

\section{Keywords}

environmental performance, environmental policy, literature review, content analysis, sustainable development 


\section{Introduction}

Environmental performance is a multidimensional construct. It includes not only the outcomes and impacts companies' have on their stakeholders and the environment, but also the principles of environmental responsibility and processes of environmental responsiveness that determine future outcomes and impacts (Orlitzky et al., 2003; Schultze \& Trommer, 2012). Environmental performance is therefore defined as the output of environmental management, that is, the effects the firm's activities and products have on the natural environment (Klassen \& Whybark, 1999; Molina-Azorin et al., 2009; Schultze \& Trommer, 2012). According to this definition, environmental management encompasses the technical and organizational activities undertaken by the firm to reduce environmental impacts and minimize their effects on the natural environment (Cramer, 1998).

Since 1989, when the Coalition for Environmentally Responsible Economies (CERES) attempted to define the notion of environmental performance, academic research has used numerous and diverse indicators in order to measure it. These indicators can refer to a level of pollution or pollution reduction, relay organizations' initiatives, or reflect a variety of practices, such as recycling and reprocessing of waste. In this way, environmental performance is measured by objective or non-objective indicators allowing evaluation of the efficiency of a firm's consumption of resources (Dixon-Fowler et al., 2013; Molina-Azorin et al., 2009). Different measurement frameworks of environmental performance integrate these indicators on internal and external axes of procedures or results to satisfy the needs of reporting, disclosure, monitoring and management of environmental performance (Curkovic, 2003; Ilinitch et al., 1998; Xie \& Hayase, 2007). Environmental performance is therefore a multidimensional concept that has both managerial and measurement dimensions (Schultze \& Trommer, 2012; Trumpp et al., 2013).

How far has academic research covered the full complexity of the environmental issue in its 
multiple dimensions? In what context has academic research used these objective and nonobjective indicators? What are the main research questions? Since academic research has linked environmental performance closely to environmental management, we question the extent to these two notions have been considered separately.

In contrast to earlier literature reviews (Azzone et al., 1996; Henri \& Giasson, 2006; MolinaAzorin et al., 2009; Rahman \& Post, 2012), and to answer my research question, I propose an inductive typology of the academic work on this topic through a content analysis of the abstracts of 151 articles that contain the key words "environmental management" and "environmental performance" in either the titles or the abstracts. Content analysis is a systematic, objective, quantitative analysis of message characteristics (Berelson, 1952; Neuendorf, 2001) that allows us to identify authors' points of view and describes the research trends in this field (Weber, 1990).

The aim of this literature review is to draw up an exhaustive and objective classification of the academic work on the multiple dimensions of environmental performance. The remainder of the paper is organized as follows. In Section 2 I review the different environmental indicators and frameworks used in academic research to measure environmental performance, and follow this with a description of the research method used (Section 3). I present the findings in Section 4 and introduce the typology of the research on environmental performance in Section 5. In the final section I discuss the findings and conclude.

\section{Measuring environmental performance}

Environmental performance is defined as the measurable results of environmental management system (EMS) in relation to the control the organization has over its environmental aspects, aims, impacts and targets based on its environmental policy (Klassen 
\& Whybark, 1999; Molina-Azorin et al., 2009). In that context, academic research has used numerous and diverse environmental performance indicators focusing either on the results of EMS (objective measures) or on the environmental practices themselves (non-objective measures) (Dixon-Fowler et al., 2013; Lopez-Gamero et al., 2009).

\section{Objective measures of environmental performance}

Academic research presents environmental indicators as observable and quantifiable variables, reflecting the different ways in which environmental impacts can be caused by a given activity (Dixon-Fowler et al., 2013; Ilinitch et al., 1998; Xie \& Hayase, 2007). These variables are given in physical, chemical, and biological units and expressed as either absolute or relative values. These proxies are positive when they measure the reduction of pollution and negative when they refer to the pollution produced. Furthermore, these data can measure resources consumed during the manufacturing process or the pollution generated by company's activity (Molina-Azorin et al., 2009). These indicators also reveal a company's past behaviour, thus making it easier to compare companies and/or activities. However, they do not allow forecasting, which would enable polluting behaviour to be monitored (Tyteca, 1996; Xie \& Hayase, 2007).

These environmental indicators are often calculated on the basis of data reported by companies through the Toxics Release Inventory (TRI) seen as a set of quality information on pollution (Hamilton, 1995; King \& Lenox, 2001), yet not as a comprehensive indicator of a firm's total environment performance (Ambec \& Lanoie, 2008). Other studies have used a pollution index drawn up by the Council of Economic Priorities (CEP) (Chen \& Metcalf, 1980; Jaggi \& Freedman, 1992), indices relating to environmental commitment, such as that of the Franklin Research \& Development Corporation (FR\&DC) (Russo \& Fouts, 1997) or the reputation index or on non-financial grading, like the KLD 400 Social Index, carried out 
by independent organizations.

Yet, the transparency and/or the validity of these databases may be incomplete (Rahman \& Post, 2012). Hence, the conclusions drawn from these studies may not address the complexity of the environmental performance issue, leading to the increasing use by researchers of nonobjective indicators to underline the management dimension (Dixon-Fowler et al., 2013).

\section{Non-objective measures of environmental performance}

Academic research has shown that environmental performance is related to the EMS implemented by the firm (Klassen \& Whybark, 1999). Moreover, Wood (1991) suggests that environmental practices and activities should be taken into consideration as soon as environmental performance is measured.

In this framework, academic research uses non-objective indicators to measure environmental performance, revealing the efforts companies make to reduce the impact of their activities on the environment (Molina-Azorin et al., 2009; Schultze \& Trommer, 2012). The implementation of EMS, the integration of environmental objectives in the firm's planning, eco-design, the product life-cycle analysis, the development of "green" products, and the company's voluntary participation in environmental programmes, are all measures of companies' environmental performance (Christmann, 2000; Molina-Azorin et al., 2009). The adoption of an EMS is often presented as an indicator of a firm's capacity for sustainable environmental commitment (Melnyk et al., 2003) and its certification is considered as a legitimate indicator of the organizational changes involved in these policies (Goh Eng et al., 2006). These non-objective measures highlight the practices implemented by firms, their goals with regard to their environmental responsibilities, and the EMS set up to manage these environmental strategies and improve environmental performance (Schultze \& Trommer, 2012). It is less a question of measuring or reducing pollution, and more about giving an 
account of the organizational changes these environmental strategies require.

\section{Research methodology}

The aim of this study is to survey the research related to environmental performance, which is defined as the result of environmental management (Klassen \& Whybark, 1999; MolinaAzorin et al., 2009; Schultze \& Trommer, 2012). A search in academic reference databases (EBSCO, EconLit, JSTOR, Academic Search Premier) of the keywords "environmental performance" and "environmental management" in titles and/or abstracts generated a sample of 151 articles published in peer-reviewed journals in the management field. For each of these references, the following characteristics were noted: publication date, journal title, track of the journal review, geographical zone of the university of the author(s), type of environmental performance indicator and type of research method. Each paper was read carefully in order to collect other useful information, such as theoretical background, research question, research design, types of indicators used in the study and the main contributions of the paper.

The scope of the study is based on the content analysis of the abstracts of these 151 articles. The choice of abstracts as an analysis sample is justified by the fact that they were written by the authors themselves in order to interest readers by presenting the main points of their work. Their compactness requires authors to select their words carefully. Thus, it is reasonable to presume that the analysis of words used in titles and abstracts will give a representative image of the whole article (Lesage \& Wechtler, 2012).

As the aim of this study is to provide an inductive typology of the academic research relating to the measurement of environmental performance, a computer-based content analysis of these abstracts was carried out. This research method uses a set of statistical procedures to 
make valid inferences from the text itself, the author or its audience. Content analysis can be used to identify the intentions and other characteristics of the communicator, reveal the focus of individuals, groups, institutional or societal attention, and describe trends in communication content (Weber, 1990). This method uses the verbal unit, as the database is particularly well suited to the case of longitudinal studies (Kabanoff et al., 1995).

Given the large number of texts and the aim of meeting the requirements of replicability, we selected the computer-aided approach (Kabanoff et al., 1995) as it reinforces face validity. We used the SPAD-T-V8 software, which provides useful frequency distributions of words, or analysis of words in context, and performs statistical analyses of textual data. This software suits quantitative narrative analysis, as it provides useful analytical tools for mapping clusters of words graphically (Franzosi, 2010). This methodology relies on textual statistics and allows the analysis of important texts on the basis of particular lexical contingencies, where the individual statistic is made up from the occurrence of a textual unit (word, lemma, segment, repeated segment) (Lebart \& Salem, 1994).

The computer-based content analysis comprises several steps. First, the software generates a dictionary of all the words present in the database as well as their frequency (the 151 abstracts contain 3,574 different words with 24,149 occurrences). Then filters are applied to eliminate tool-words and articles in order to confine the dictionary to main words. In the case of homonyms, the software allows the user to consider the context of the word in order to decide whether or not to keep it. The lemmatization process that follows allows the user to bring together complex words related to the same semantic group. In this way, groups of words with the same roots can be formed around a significant keyword (Bolden \& Moscarola, 2000). Finally, a second elimination phase allows the removal of words that appear infrequently. In this case the final dictionary is made up of 72 keywords representing $47.49 \%$ of occurrences.

Moving on from studying the words alone, I used the contingencies table (item*words) on 
which I ran a factorial correspondence analysis (FCA) with environmental performance as an active variable and the other variables as illustrative variables. This factorial correspondence analysis is completed by a classification of the keywords using a hierarchical cluster analysis. This last phase reveals a typology of four classes of significant keywords. The study of these classes reveals the characteristics of the academic research. The use of these statistical methods makes it possible to carry out an exploratory study of the content of the texts (Guerin-Pace, 1998) and present a typology of the significant keywords (Franzosi, 2010).

\section{Findings}

One major theme stands out in this typology (Table 1). "The relationship between environmental management and financial performance" represents almost $35 \%$ of the academic literature on the measurement of environmental performance. Initially academic research tried to reassure shareholders, the principal providers of resources for the firm, through empirical studies of the relationship between environmental and financial performance. The objective indicators of environmental performance have been widely used to test Porter's win-win hypothesis (1995) and verify how far environmental performance improves financial performance. In the light of these studies it seems that the relationship between environmental and financial performance is positive (Dechant \& Altman, 1994; Hart \& Ahuja, 1996; Madsen, 2008; Menguc et al., 2010; Montabon et al., 2007; Russo \& Fouts, 1997; Wagner \& Schaltegger, 2004; Walls et al., 2011), even if some studies tend to prove the opposite (Cordeiro \& Sarkis, 1997; Hassel et al., 2005; Jaggi \& Freedman, 1992; McPeak et al., 2010), while others maintain it is impossible to prove (Christmann, 2000; Darnall, 2009; King \& Lenox, 2001).

Despite a number of limitations, such as the diversity of environmental performance 
indicators or the variety of research methods, these works show that environmental performance improves financial performance to a certain degree (Albertini, 2013). It has a greater improvement effect on a company's accounting financial performance than its marketbased financial performance. Indeed, pollution prevention activities that are carried out within the framework of an environmental strategy imply that production processes should be modified in order to reduce energy consumption; production costs would be reduced, too, leading to competitive advantages (Al-Najjar \& Anfimiadou, 2012; Lopez-Gamero et al., 2009; Wagner, 2005). Moreover, the sale of environmentally friendly products allows companies to obtain a leading position in emerging markets for "green" products (Hart, 1995). Nevertheless, this relation has to be placed in a long-term context since it relies on very heavy investments, which tend initially to penalise profitability before eventually serving companies' purposes. Some authors have pointed out that the lack of a theoretical background does not allow for efficient testing of the link between environmental and financial performance (Cormier et al., 2004; Wagner \& Schaltegger, 2003).

Two further themes emerge from this typology, each representing almost $24 \%$ of the vocabulary.

The first is "Environmental management and institutional pressures", highlighting the two main kinds of pressure from civil society and government. The academic research on institutional pressures shows how much the firm is at the heart of a set of relationships with partners that include shareholders as well as actors interested in its activities and decisions (Hoffman, 2001). The research highlights the determining roles of government, civil society, certification organizations, media and other companies in the same sector in the introduction of environmental actions and the disclosure of environmental information (Brammer \& Pavelin, 2008; Christmann, 2004; Dechant \& Altman, 1994; Sharma \& Henriques, 2005). Among these pressures, environmental regulations require companies regularly to 
communicate information on their ecological footprint and greenhouse gas monitoring in order to satisfy environmental standards (Delmas \& Toffel, 2004; Sharma, 2000). A significant increase in environmental disclosure leads academic research to study its possible exploitation by companies as a way of managing public impressions or of increasing legitimacy (Cormier \& Magnan, 1999). The need to reassure worried stakeholders motivates companies to disclose very detailed reports that encourage stakeholders to give more rapid approval to a polluting industrial activity (Sinclair-Desgagné \& Gozlan, 2003). The optimistic tone adopted by companies in their annual reports or on their websites may mask poor ecological performance and does not allow the classification of firms according to their environmental performance (Cho et al., 2010).

The other theme that represents almost $24 \%$ of the vocabulary is "Increasing awareness of the environmental issue". The research focuses on very concrete topics such as pollution, sustainability and ecological issues through objective indicators used in empirical studies. This relatively recent field of study interests mainly Asian or North American researchers publishing in accounting and auditing reviews. In the context of "ecological" issues, researchers refer to the need for a more sustainable way of manufacturing that seeks to reduce the carbon footprint. These studies mention regulatory or voluntary approaches to pollution control implemented by companies in order to reduce pollution levels. The keyword "sustainability" refers to the preference for a sustainable development approach rather than a financial approach. These studies insist that corporate sustainable performance should meet economic performance goals.

The final theme emerging from this typology is "Strategic management of environmental performance and environmental reporting" and represents $18 \%$ of the vocabulary. NRBV articles try to identify the dynamic and inimitable organizational capacities that enable a 
company to gain a strong competitive advantage through a proactive environmental strategy (Aragon-Correa \& Sharma, 2003; Dangelico \& Pontrandolfo, 2015; Hart \& Dowell, 2011). This competitive advantage relies on the company's capacity to bring together all its resources (human, financial, material) by applying knowledge and know-how within the framework of an environmental strategy (Judge \& Douglas, 1998). It allows firms to invest in new and unexplored markets for green products in advance of their competitors and sometimes even influences future regulations by presenting their expertise to the government (Porter \& van der Linde, 1995). This research theme is based on non-objective indicators that highlight environmental innovations, staff training, setting up a dedicated department and planning the roll out of environmental practices (Christmann, 2000; Menguc \& Ozanne, 2005; Nakao et al., 2007). The research underlines the association of the reporting of environmental performance and the management of this performance for companies that interact with external actors, such as their supply chain strategies (Darnall et al., 2008; Handfield et al., 2005). Environmental performance indicators may have an external value for environmental reporting purposes or an internal value for managing the corporate environmental performance. This corresponds to two logics of the representation of environmental performance (Xie \& Hayase, 2007).

Insert Table 1 here

\section{Discussion and conclusion}

To sum up, research on the measurement of environmental performance centres around four major themes: (1) the relationship between environmental management and financial 
performance; (2) environmental management and institutional pressures; (3) toward an increasing awareness of the environmental issue and (4) strategic environmental management and reporting. This typology illustrates the varied contexts in which environmental performance indicators have been used in academic research, and the efforts made by researchers to cover the complexity of the environmental management issue. Academic research shows that an increasing number of companies use objective and non-objective indicators to measure their environmental performance with the aim of managing this performance internally and reporting the information to institutional stakeholders in conformity with regulations. In addition, the joint use of objective and non-objective indicators by academic research underlines the interdependence of these indicators to measure environmental performance in line with its definition (Arjaliès \& Mundy, 2013).

From this typology, we can draw some conclusions about what we know about the environmental policy literature.

First, the research questions as well as the context of the studies have determined the different uses of environmental performance indicators. Numerous empirical studies of the relationship between environmental and financial performance have caused the academic research to digress from the main question, which is how to measure the impact of corporate activities on the natural environment. The same goes for academic research that studies environmental disclosure as a way for companies to gain or maintain their legitimacy. These studies use environmental indicators not to measure the negative externalities caused by companies (Larrinaga et al., 2002) but rather to determine the financial consequences of environmental practices or the extent to which companies are practising "greenwashing" (Cho, 2009). Furthermore, studies about the relationship between environmental and financial performance have not reached a consensus about the strength of the relationship. Even if the overall relationship is positive, the kind of indicators chosen to measure either environmental or 
financial performance deeply influences the strength of the relationship (Albertini, 2013). This lack of consensus on how to measure environmental performance and its consequences on financial performance contributes to the lack of theoretical foundation, calling into question the knowledge convergence (Aragon-Correa \& Sharma, 2003).

Second, the different theoretical backgrounds chosen by researchers clearly influence the way the environmental issue is studied. The stakeholder perspective highlights conflicting pressures from internal (customers, employees, stockholders) and external (regulators, environmental activists, non-governmental organizations) stakeholder groups (Clarkson, 1995). Institutional theory suggests that rules, customs or beliefs guide and constrain the behaviour of organizations (Scott, 2008). Hence, studies in these academic streams have often posited the environmental commitment of companies as an answer to stakeholders' demands or institutional constraints in a reactive rather than a proactive way.

Third, the definition of environmental performance is ambiguous since it refers to the management of environmental performance as well the results of management. Yet, these two notions are independent of one another (Lopez-Gamero et al., 2009). The management of environmental performance does not lead systematically to a reduction in pollution caused by a company's activities. Some environmental practices stimulate financial incomes, allowing companies to increase their profitability without reducing the impact of their activities on the natural environment (Bansal \& Knox-Hayes, 2013). Furthermore, companies take advantage of this multiple definition of environmental performance. They can disclose significant information about their environmental management practices through their annual reports, even if these practices are inadequate when it comes to reducing the pollution caused by their activities. The lack of audit of their environmental results allows companies to disclose their environmental management practices with the aim of maintaining or increasing their legitimacy (Cormier et al., 2005). Thus, the ambiguous definition of environmental 
performance prevents not only a clear understanding of this issue but also the development of a theoretical foundation (Hoffman \& Bansal, 2012).

Fourth, this study underlines the different contexts in which the indicators have been used in academic research to measure environmental performance. There is no doubt that environmental performance is quantified with the aim of measuring the relationship between environmental and financial performance and determining its significance. Nevertheless, the research has evolved little by little towards a more managerial dimension of environmental performance, as shown by the increasing use of non-objective as well as objective indicators. This may highlight a significant change in research question. Indeed, after studying why companies implement environmental strategy and how far this impacts financial performance, it seems that research is more about how companies address the consequences of climate change that impact their corporate business strategy. Even in developed countries, the increasing scarcity of certain resources obliges companies to modify their manufacturing process in order to make them more energy efficient. Indeed, physical impacts from climate change pose major challenges for organizations (Winn et al., 2011) and determine the environmental strategies (Sprengel \& Bush, 2011).

Fifth, limits to the indicators themselves can be highlighted. This typology demonstrates that some research features indicators of questionable accessibility and reliability. Moreover, these objective indicators do not allow us to attribute improvement in environmental performance to any one specific pollution prevention practice because the connections between a company's activities and the natural environment are complex. As for the non-objective indicators mobilized during the research, they are directly linked to the company and its activity, making generalization and repeat studies very difficult. Moreover, the validity of the use of non-objective indicators to measure the environmental performance of companies has still not been established empirically (Ilinitch et al., 1998). 
From this typology based on the environmental policy literature, we can know suggest an agenda for future research.

First, as this typology has highlighted, environmental performance indicators seem to be a significant communication tool in the relationship between a company and its external stakeholders. Indeed, firm's environmental disclosure enhances the quality of the analysts' information context, which ultimately allows them to make better forecasts (Cormier \& Magnan, 2015). It would be interesting to study the extent to which environmental disclosure is a part of integrated reporting for companies and what types of indicator are used in this specific reporting (Jensen, 2012). Furthermore, it may be interesting to determine the extent to which a company can comply with mandatory external reporting and manage environmental performance internally using the same indicators. In other words, can environmental performance indicators be used to report environmental performance to external stakeholders and at the same time be used to manage that performance internally to satisfy shareholders? Second, environmental performance is measured through objective indicators that highlight the consequences of corporate activities on the natural environment and non-objective indicators that enhance knowledge about the environmental practices implemented by companies. It might be interesting to study the extent to which the joint use of these indicators through a management control system could help companies to obtain a sustainable competitive advantage from environmental issues. Third, the lack of consensus about the relationship between environmental and financial performance seems to show that this relationship may be indirect rather than direct (Aragon-Correa \& Sharma, 2003; LopezGamero et al., 2009). Thus, there is a need to study the potential moderator or mediator of this relationship, such as corporate strategies (Wagner, 2005), environmental innovation (Forsman, 2013) or organizational capabilities and resources (Aragon-Correa \& Sharma, 2003; Dangelico \& Pontrandolfo, 2015). Indeed, technological capital such as innovative 
capacity, relational capital such as relationships with customers and business partners, or human capital such as training could be significant mediators in the relationship between environmental policy and financial performance. Furthermore, as the strength of this relationship differs according to the type of financial performance indicators used in empirical studies, further research might question a financial indicator that could reflect the long-term return on investment of these environmental practices and the competitive advantage they provide to the company as well. Fourth, as these capabilities provide a sustainable competitive advantage, further research might seek to enhance knowledge about the kind of capabilities and resources that need to be developed from a contingent resource-based perspective (Aragon-Correa et al., 2008). Since the success of proactive environmental strategies rely on organizational capabilities such as a shared vision of the environmental issues within the company, stakeholder pressure management, business redefinition, environmental product innovation and new process design to reduce pollution (Aragon-Correa et al., 2008), further research could study how companies enhance the development and the implementation of these capabilities. Indeed, qualitative studies, such as case studies, might enhance significantly our knowledge of these deeply embedded organizational capabilities. Fifth, since academic research has mainly focused on the top managers' role in the commitment of the firm to a proactive environmental strategy, research on the specific role of the employees in the environmental decision-making process could enhance the knowledge of the microfoundations of the environmental policy success (Torre-Ruiz et al., 2015). Indeed, organizational citizenship behaviours for the environment, based on individual and voluntary initiatives, are increasingly considered as an essential ingredient of corporate greening (Boiral, 2009; Boiral et al., 2015; Temminck et al., 2015). In that context, research can study to what extent employees of a proactive environmental company generate a positive 'word of mouth' influencing consumers' way of purchase. 
To conclude, this typology highlights four major themes around which the academic research is organized: the relationship between environmental management and financial performance; environmental management and institutional pressures; toward an increasing awareness of the environmental issue and strategic environmental management and reporting. From this typology, several future research questions could be addressed such as the possible connection between the environmental disclosure and the integrated reporting, the influence of mediators or moderators on the relationship between environmental policy and financial performance, the extent to which a management control systems can enhance the efficiency of the environmental strategy and the resources and the capabilities that need to be developed to improve the competitive advantage generated by an environmental policy.

\section{Reference}

Al-Najjar, B., \& Anfimiadou, A. 2012. Environmental Policies and Firm Value. Business Strategy and the Environment 1: 49-59.

Albertini, E. 2013. Does Environmental Management Improve Financial Performance? A Meta-Analytical Review. Organization \& Environment 4: 431-457.

Ambec, S., \& Lanoie, P. 2008. Does It Pay to Be Green? A Sytematic Overview. Academy of Management Perspective 4: 45-62.

Aragon-Correa, J. A., Hurtado-torres, N., Sharma, S., \& Garcia-Morales, V. J. 2008. Environmental Strategy and Performance in Small Firms: A Resource-Based Perspective. Journal of Environmental Management 1: 88-103.

Aragon-Correa, J. A., \& Sharma, S. 2003. A Contingent Resource-Based View of Proactive Corporate Environmental Strategy. Academy of Management Review 1: 71-88.

Arjaliès, D. L., \& Mundy, J. 2013. The Use of Management Control Systems to Manage CSR Strategy: A Levers of Control Perspective. Management Accounting Research 4: 284300.

Azzone, G., Noci, G., Manzini, R., Welford, R., \& Young, C. W. 1996. Defining Environmental Performance Indicators: An Integrated Framework. Business Strategy and the Environment 2: 69-80.

Bansal, P., \& Knox-Hayes, J. 2013. The Time and Space of Materiality in Organizations and the Natural Environment. Organization \& Environment 1: 61-82.

Berelson, B. 1952. Content Analysis in Communication Research. New York: Hafner

Boiral, O. 2009. Greening the Corporation Through Organizational Citizenship Behaviors. 2009 2: 221-236.

Boiral, O., Talbot, D., \& Paillé, P. 2015. Leading Example: A Model of Organizational Citizenship Behavior for the Environment. Business Strategy and the Environment 6: 532-550. 
Bolden, R., \& Moscarola, J. 2000. Bridging the Quantitative-Qualitative Divide: The Lexical Approach to Textual Data Analysis. Social Science Computer Review 4: 450-460.

Brammer, S., \& Pavelin, S. 2008. Factors influencing the quality of corporate environmental disclosure. Business Strategy and the Environment 2: 120-136.

Chen, K. H., \& Metcalf, R. W. 1980. The Relationship Between Pollution Control Record and Financial Indicators Revisited. The Accounting Review 1: 168-177.

Cho, C. H. 2009. Legitimation Strategies Used in Response to Environmental Disaster: A French Case Study of Total SA's Erika and AZF Incidents. European Accounting Review 1: 33-62.

Cho, C. H., Roberts, R. W., \& Patten, D. M. 2010. The Language of US Corporate Environmental Disclosure. Accounting, Organizations and Society 4: 431-443.

Christmann, P. 2000. Effects of "Best Practices" of Environmental Management on Cost Advantage: the Role of Complementary Assets. Academy of Management Journal 4: 663-680.

Christmann, P. 2004. Multinational Companies and the Natural Environment: Determinants of a Global Environmental Policy Standardization. Academy of Management Journal 5: 747-760.

Clarkson, M. B. E. 1995. A Stakeholder Framework for Analysis and Evaluating Corporate Social Performance. Academy of Management Review 1: 92-117.

Cordeiro, J. J., \& Sarkis, J. 1997. Environmental Proactivism and Firm Performance: Evidence from Security Analyst Earnings Forecasts. Business Strategy and the Environment 2: 101-114.

Cormier, D., Gordon, I. M., \& Magnan, M. 2004. Corporate Environmental Disclosure: Contrasting Management's Perception with Reality. Journal of Business Ethics 2: 143165.

Cormier, D., \& Magnan, M. 1999. Corporate Environmental Disclosure Strategies: Determinants, Costs and Benefits. Journal of Accounting, Auditing \& Finance 4: 429451.

Cormier, D., \& Magnan, M. 2015. The Economic Relevance of Environmental Disclosure and its Impact on Corporate Legitimacy: An Empirical Investigation. Business Strategy and the Environment 6: 431-450.

Cormier, D., Magnan, M., \& Velthoven, B. V. 2005. Environmental Disclosure Quality in Large German Companies: Economics Incentives, Public Pressures or Institutional Conditions. European Accounting Review 1: 3-39.

Cramer, J. 1998. Environmental Management: from 'fit' to 'stretch'. Business Strategy and the Environment 7: 162-172.

Curkovic, S. 2003. Environmentally Responsible Manufacturing: The Development and Validation of a Measurement Model. European Journal of Operational Research 1: 131-155.

Dangelico, R. M., \& Pontrandolfo, P. 2015. Being 'Green and Competitive': The Impact of Environmental Actions and Collaborations on Firm Performance. Business Strategy and the Environment 6: 413-430.

Darnall, N. 2009. Regulatory Stringency, Green Production Offsets, and Organizations' Financial Performance. Public Administration Review 3: 418-434.

Darnall, N., Jolley, G. J., \& Handfield, R. 2008. Environmental management systems and green supply chain management: complements for sustainability. Business Strategy and the Environment 1: 30-45.

Dechant, K., \& Altman, B. 1994. Environmental Leadership: From Compliance to Competitive Advantage. Academy of Management Executive 3: 7-20. 
Delmas, M., \& Toffel, M. W. 2004. Stakeholders and Environmental Management Practices: An Institutional Framework. Business Strategy and the Environment 4: 209-222.

Dixon-Fowler, H. R., Slater, D. J., Johnson, J. L., Ellstrand, A. E., \& Romi, A. M. 2013. Beyond "Does it Pay to be Green?" A Meta-Analysis of Moderators of the CEP-CFP Relationship. Journal of Business Ethics 2: 353-366.

Forsman, H. 2013. Environmental Innovations as a Source of Competitive Advantage or Vice Versa? Business Strategy and the Environment 5: 306-320.

Franzosi, R. 2010. Quantitative Narrative Analysis. Quantitative applications in the social sciences, Sage Publications: Thousand Oaks pp 175.

Goh Eng, A., Zailani, S., \& Wahid, N. A. 2006. A Study on the Impact of Environmental Management System (EMS) Certification toward Firm's Performance in Malaysia. Management of Environmental Quality 1: 73-93.

Guerin-Pace, F. 1998. Textual Statistics. An Exploratory Tool for the Social Sciences. Population 1: 73-95.

Hamilton, J. T. 1995. Pollution as News: Media and Stock Market Reactions to the Toxics Release Inventory Data. Journal of Environmental Economics and Management 1: 98113.

Handfield, R., Sroufe, R., \& Walton, S. 2005. Integrating Environmental Management and Supply Chain Strategy. Business Strategy and the Environment 1: 1-19.

Hart, S. L. 1995. A Natural-Resource-Based View of the Firm. Academy of Management Review 4: 996-1014.

Hart, S. L., \& Ahuja, G. 1996. Does it pay to be green? An empirical examination of the relationship between emission reduction and firm performance. Business Strategy and the Environment 1: 30-37.

Hart, S. L., \& Dowell, G. 2011. A Natural-Resource-Based View of the Firm: 15 Years After. Journal of Management (Invited Editorial) 5: 1464-1479.

Hassel, L., Nilson, H., \& Nyquist, S. 2005. The Value Relevance of Environmental Performance. European Accounting Review 1: 41-61.

Henri, J.-F., \& Giasson, A. 2006. Measuring Environmental Performance: a Basic Ingredient of Environmental Management. CMA Management 28-32.

Hoffman, A. J. 2001. Linking Organizational and Field-Level Analysis: The Diffusion of Corporate Environmental Practice. Organization \& Environment 2: 133-156.

Hoffman, A. J., \& Bansal, P. 2012. Retrospective, Perspective and Prospective: Introduction to the Oxford Handbook on Business and the Natural Environment. Edited by Bansal and Hoffman

Ilinitch, A. Y., Soderstrom, N. S., \& Thomas, T. E. 1998. Measuring Corporate Environmental Performance. Journal of Accounting and Economics 4-5: 383-408.

Jaggi, B., \& Freedman, M. 1992. An Examination of the Impact of Pollution Performance on Economic and Market Performance: Pulp and Paper Firms. Journal of Business Finance \& Accounting 5: 697-713.

Jensen, J. C. 2012. Determinants of Traditional Sustainability Reporting Versus Integrated Reporting . An Institutionalist Approach. Business Strategy and the Environment 5: 299-316.

Judge, W. Q., \& Douglas, T. J. 1998. Performance Implications of Incorporating Natural Environmental Issues into Strategic Planning Process: an Empirical Assessment. Journal of Management Studies 2: 241-262.

Kabanoff, B., Waldersee, R., \& Cohen, M. 1995. Espoused Values and Organizational Change Themes. Academy of Management Journal 4: 1075-1104. 
King, A., \& Lenox, M. 2001. Does it Really pay to be Green? An Empirical Study of Firm Environmental and Financial Performance. The Journal of Industrial Ecology 1: 105116.

Klassen, R. D., \& Whybark, D. C. 1999. The Impact of Environmental Technologies on Manufacturing Performance. Academy of Management Journal 6: 599-615.

Larrinaga, C. F., Carrasco, F., Correa, C., Llena, F., \& Moneva, J. M. 2002. Accountability and Accounting Regulation: the Case of Spanish Environmental Disclosure Standard. The European Accounting Review 4: 723-740.

Lebart, L., \& Salem, A. 1994. Statistiques Textuelles. Dunod, Paris 342 p.

Lesage, C., \& Wechtler, H. 2012. An Inductive Typology of Auditing Research. Contemporary Accounting Research 2: 487-504.

Lopez-Gamero, M. D., Molina-Azonrin, J. F., \& Claver-Cortes, E. 2009. The whole relationships between environmental variables and firm performance: Competitive advantage and firm resources as mediator variables. Journal of Environmental Management 10: 3110-3121.

Madsen, P. M. 2008. Environmental Regulation as a Link Between Corporate Environmental and Financial Performance. Academy of Management Proceedings 1-6.

McPeak, C., Devirian, J., \& Seaman, S. 2010. Do Environmentally Friendly Companies Outperform the Market? The Journal of Global Business Issues 1: 61-66.

Melnyk, S. A., Sroufe, R. P., \& Calantone, R. 2003. Assessing the Impact of Environmental Management Systems on Corporate and Environmental Performance. Journal of Operations Management 3: 329-351.

Menguc, B., Auh, S., \& Ozanne, L. K. 2010. The Interactive Effect of Internal and External Factors on a Proactive Environmental Strategy and its Influence on a Firm's Performance. Journal of Business Ethics 2: 279-298.

Menguc, B., \& Ozanne, L. K. 2005. Challenges of the "Green Imperative": a Natural Resource-Based Approach to the Environmental Orientation-Business Performance Relationship. Journal of Business Research 4: 430-438.

Molina-Azorin, J. F., Claver-Cortés, E., Lopez-Gamero, M. D., \& Tari, J. J. 2009. Green Management and Financial Performance: a Literature Review. Management Decision 7: 1080-1100.

Montabon, F. R., Sroufe, R. P., \& Narisimhan, R. 2007. An Examination of Corporate Reporting, Environmental Management Practices and Firm Performance. Journal of Operations Management 5: 998-1014.

Nakao, Y., Amano, A., Matsumura, K., Genba, K., \& Nakano, M. 2007. Relationship Between Environmental Performance and Financial Performance: an Empirical Analysis of Japanese Corporations. Business Strategy and the Environment 2: 106118.

Neuendorf, K. A. 2001. The Content Analysis Guidebook. Sage Publications pp 301.

Orlitzky, M., Schmidt, F. L., \& Rynes, S. L. 2003. Corporate Social and Financial Performance: A Meta-Analysis. Organization Studies 3: 403-441.

Porter, M. E., \& van der Linde, C. 1995. Toward a New Conception of the EnvironmentCompetitiveness Relationship. Journal of Economic Perspectives 4: 97-118.

Rahman, N., \& Post, C. 2012. Measurement Issues in Environmental Corporate Social Responsability (ECSR): Toward a Transparent, Reliable, and Construct Valid Instrument. Journal of Business Ethics 3: 307-319.

Russo, M. V., \& Fouts, P. A. 1997. A Resource-Based Perspective on Corporate Environmental Performance and Profitability. Academy of Management Journal 3: 534-559. 
Schultze, W., \& Trommer, R. 2012. The Concept of Environmental Performance and its Measurement in Empirical Studies. Journal of Management Control 4: 375-412.

Scott, W. R. 2008. Institutions and Organisations: Ideas and Interests. Los Angeles: Sage Publications

Sharma, S. 2000. Managerial Interpretations and Organizational Context as Predictors of Corporate Choice of Environmental Strategy. Academy of Management Journal 4: 681-697.

Sharma, S., \& Henriques, I. 2005. Stakeholder Influences on Sustainability Practices in the Canadian Forest Products Industry. Strategic Management Journal 2: 159-180.

Sinclair-Desgagné, B., \& Gozlan, E. 2003. A Theory of Environmental Risk Disclosure. Journal of Environmental Economics and Management 2: 2-15.

Sprengel, D. C., \& Bush, T. 2011. Stakeholder Engagement and Environmental Strategy - The Case of Climate Change. Business Strategy and the Environment 6: 351-364.

Temminck, E., Mearns, K., \& Fruhen, L. 2015. Motivating Employees toward Sustainable Behaviour. Business Strategy and the Environment 6: 402-412.

Torre-Ruiz, J. M., Aragon-Correa, J. A., \& Martin-Tapia, I. 2015. Do Individual Preferences Affect the Environmental Decision-Making Process in Teams? The Role of Participation. Business Strategy and the Environment 6: 451-465.

Trumpp, C., Endrikat, J., Zopf, C., \& Guenther, E. 2013. Definition, Conceptualization, and Measurement of Corporate Environmental Performance: A Critical Examination of a Multidimensional Construct. Journal of Business Ethics 2: 185-204.

Tyteca, D. 1996. On the Measurement of the Environmental Performance of Firms. A Literature Review and a Proactive Efficiency Perspective. Journal of Environmental Management 3: 281-308.

Wagner, M. 2005. How to reconcile environmental and economic performance to improve corporate sustainability: corporate environmental strategies in the European paper Industry. Journal of Environmental Management 2: 105-118.

Wagner, M., \& Schaltegger, S. 2003. How Does Sustainability Performance Relate to Business Competitiveness? Greener Management International 44: 5-16.

Wagner, M., \& Schaltegger, S. 2004. The Effect of Corporate Environmental Strategy Choice and Environmental Performance on Competitiveness and Economic Performance: An Empirical Study of EU Manufacturing. European Management Journal 5: 557-572.

Walls, J. L., Phan, P. H., \& Berrone, P. 2011. Measuring Environmental Strategy: Construct Development, Relaibility, and Validity. Business \& Society 1: 71-115.

Weber, R. P. 1990. Basic Content Analysis 2nd ed Newbury Park, CA : Sage

Winn, M., Kirchgeorg, M., Griffiths, D., Linnenluecke, M. K., \& Günther, E. 2011. Impacts from Climate Change on Organizations: A Conceptual Foundation. Business Strategy and the Environment 3: 157-173.

Wood, D. J. 1991. Social Issues in Management: Theory and Research in Corporate Social Performance. Journal of Management 2: 383-406.

Xie, S., \& Hayase, K. 2007. Corporate Environmental Performance: a Measurement Model and a New Concept. Business Strategy and the Environment 2: 148-168. 
Table 1

Typology of the research relative to the measurement of environmental performance

\begin{tabular}{|c|c|c|c|}
\hline Theme & $\begin{array}{l}\text { No. of } \\
\text { words }\end{array}$ & $\begin{array}{l}\text { Theme } \\
\text { characteristics }\end{array}$ & $\begin{array}{l}\text { Theme keywords } \\
\text { (in bold: most characteristic } \\
\text { and maximum contribution ) }\end{array}$ \\
\hline $\begin{array}{l}\text { The relationship } \\
\text { between } \\
\text { environmental } \\
\text { management and } \\
\text { financial } \\
\text { performance }\end{array}$ & 25 & $\begin{array}{l}\text { Empirical studies, } \\
\text { objective indicator, } \\
\text { organization and } \\
\text { production reviews, } \\
\text { first period (1992-- } \\
2000)\end{array}$ & $\begin{array}{l}\text { Achievement, company, consumption, } \\
\text { development, disclosure, factor, financial, } \\
\text { implementation, human resource, } \\
\text { implications, improvement, indicators, } \\
\text { innovation, integration, issue, leadership, } \\
\text { manufacturing, measurement, perception, } \\
\text { performance, proactive, reduction, relation, } \\
\text { role, shareholder }\end{array}$ \\
\hline $\begin{array}{l}\text { Environmental } \\
\text { management and } \\
\text { institutional } \\
\text { pressures }\end{array}$ & 17 & $\begin{array}{l}\text { Non-objective } \\
\text { indicator, case } \\
\text { study, normative } \\
\text { study, agriculture } \\
\text { and environment } \\
\text { reviews }\end{array}$ & $\begin{array}{l}\text { Certification, EMS, framework, green, } \\
\text { industry, legitimacy, management, market, } \\
\text { new, operation, practices, production, } \\
\text { quality, regulation, stakeholder, supply, } \\
\text { technology }\end{array}$ \\
\hline $\begin{array}{l}\text { Increasing } \\
\text { awareness of the } \\
\text { environmental } \\
\text { issue }\end{array}$ & 17 & $\begin{array}{l}\text { Objective indicators, } \\
\text { empirical studies, } \\
\text { last period ( } 2008- \\
\text { 15), Asian and US } \\
\text { study area, } \\
\text { accounting and } \\
\text { auditing reviews }\end{array}$ & $\begin{array}{l}\text { Agricultural, benefit, capability, control, } \\
\text { cost, decision, ecological, Economic, } \\
\text { effective, increase, information, investment, } \\
\text { long, pollution, process, sustainability, } \\
\text { value }\end{array}$ \\
\hline $\begin{array}{l}\text { Strategic } \\
\text { environmental } \\
\text { management and } \\
\text { reporting }\end{array}$ & 13 & $\begin{array}{l}\text { Objective and non- } \\
\text { objective indicators, } \\
\text { second period } \\
\text { (2001-7), human } \\
\text { resources reviews }\end{array}$ & $\begin{array}{l}\text { Adoption, board, commitment, competitive, } \\
\text { goal, institutionalization, mediator, policy, } \\
\text { pressure, public, reporting, resource-based, } \\
\text { strategy }\end{array}$ \\
\hline
\end{tabular}

